\title{
Inclusion of fluted pumpkin (Telfaria occidentalis) fortified bread waste in broiler chickens' diets
}

\author{
Muyiwa Adegbenro* (D), Oluwafemi A. Ayeni, Johnson O. Agbede and Valentine A. Aletor
}

\begin{abstract}
Background: The objective of this study was to produce a least-cost ration from the use of fluted pumpkin leaf meal and bread waste in broiler chickens' diets. Fluted pumpkin leaves (FPL) were sourced in Akure and its environs. The leaves were air-dried and milled to produce fluted pumpkin leaf meal (FPLM), while bread wastes were collected from different bakeries in Ilara-mokin and Akure towns, Ondo State, Nigeria. The bread wastes were sun-dried and milled and tagged BWM. The fluted pumpkin meal and bread waste meal were mixed in ratio 1:9 (1 $\mathrm{kg} \mathrm{FPLM}+9 \mathrm{~kg}$ BWM) to produce the fortified bread waste meal (FBWM) and used as one of the feed ingredients in broiler chickens' diets. The FBWM were included in the diets at 0, 5, 10 and 15\% to serve as diets I, II, III and IV, respectively. Two hundred day-old Abor-acre broiler chicks were randomly allotted to the four (4) dietary treatments at fifty (50) chicks per treatment at five (5) replicates per treatment in a completely randomized design. The experimental diets (starter and finisher) and freshwater were offered to the chicks ad libitum for fifty-six (56) days.
\end{abstract}

Results: The results showed that the final weights and total weight gain were significantly $(P<0.05)$ influenced by dietary treatments. The highest final weight $(2.12 \pm 13.16 \mathrm{~kg} / \mathrm{bird})$ and the highest total weight gain $(2.08 \pm 13.14$ $\mathrm{kg} / \mathrm{bird}$ ) were recorded in birds fed diet l, while the lowest final weight $(1.73 \pm 11.67 \mathrm{~kg} / \mathrm{bird})$ and the lowest total weight gain $(1.69 \pm 11.15 \mathrm{~kg} / \mathrm{bird})$ were recorded in birds fed diet IV. There was no significant $(P>0.05)$ difference in the feed conversion ratio for all birds fed diets I-IV. The highest dressed weight $(92.64 \pm 8.30 \%)$ and the highest eviscerated weight $(79.52 \pm 6.50 \%)$ were recorded in birds fed diet l. The lowest cholesterol $(21.23 \pm 3.15 \mathrm{mg} / \mathrm{dl})$ was recorded in bird fed diet IV and the highest $(32.78 \pm 3.78 \mathrm{mg} / \mathrm{dl})$ in birds fed diet l. Highest net profit ( $\mathrm{N} 683.27$ ) was recorded in bird fed diet IV.

Conclusion: Conceivably, within the limit of this study, the inclusion of FBWM in the diet of broiler chickens at 0\% had better results than other test diets, but looking at the level of significant, up to $5 \%$ is practicable considering the final weight and weight gain. Bird fed 15\% yielded the highest profit/bird produced.

Keywords: Bread waste, Fluted pumpkin leaf meal, Performance, Carcass, Organs, Blood parameters, Broiler chickens

\section{Introduction}

A major challenge in the livestock industry is increasing price of a conventional feedstuff with the resultant effect of shortage in animal protein and high cost of poultry production and hence poor animal protein intake among

* Correspondence: madegbenro@futa.edu.ng

Department of Animal Production \& Health, The Federal University of Technology, Akure, Nigeria
Nigerians (Olabode, 2008). To match this demand as well as producing broiler chickens at a reduced cost, use of cheaper, locally available and unconventional feed resources will be the answer. The search for these feedstuffs has remained central to research efforts of an animal nutritionist (Fasuyi, 2000); all aimed at reducing the cost of broiler production through the use of cheaper feeds. Therefore, there is a need to explore the 
use of agro-industrial by-products as feed sources that can yield the same output as conventional feedstuff and perhaps at a cheaper cost. This will help to reduce the cost of feeds and also minimize the direct competition between human and animal for the availability of conventional feeds. One of the agro-industrial wastes that have received little research attention is bread waste. Large numbers of bread factories are operated in the urban and peri-urban areas, and it produces a sizable amount of wastes during processing and marketing of the bread, which in most cases contribute to environmental menace. Bread waste had been used as an alternative energy source for maize in poultry diets (Nworgu et al., 1999). However, it is envisaged that the nutritive potential of bread waste could be enhanced with the addition of fluted pumpkin (Telfairia occidentalis). Fluted pumpkin is rich in protein, vitamins and minerals (Ladeji et al., 1995 and Adegbenro, 2015). Telfairia occidentalis is also rich in iron and has been reported to be useful in the treatment of anaemia (Alada, 2000). Eating meals rich in fluted pumpkin leaves and seeds helps in preventing cancer, improves blood count, beats diabetes, and reduces blood glucose and cholesterol levels (Ajibade et al., 2001). It is therefore conceivable that a rational blend of bread wastes with fluted pumpkin leaf meal could help to increase the nutrient density vis-à-vis availability of bread wastes in broiler chicken diet. Thus, this study is designed to evaluate the nutritive potential of bread waste-fluted pumpkin leaf meal in broiler chicken diets using growth indices and health status as response criteria.

\section{Materials and methods}

\section{Experimental site}

The experiment was carried out at the Poultry Section (Broiler Unit) of the Teaching and Research Farm, The Federal University of Technology, Akure, Nigeria. The Federal University of Technology, Akure, Nigeria, is located on Latitude $7^{\circ} 18^{\prime \prime} \mathrm{N}$ and Longitude $5^{\circ} 10^{\prime \prime} \mathrm{E}$, which falls within the rainforest zone of the humid tropics, which is characterized by the hot and humid climate.

\section{Collection of tested ingredients}

Fluted pumpkin leaves were sourced for in large quantities in Akure and its environs. The leaves were air-dried between 14-21 days and the air-dried leaves were milled using hammer mill at the Nutrition Laboratory of the Department of Animal Production and Health, The Federal University of Technology, Akure, Nigeria. Also, bread wastes were collected from different bakeries in Ilaramokin and Akure both in Ondo State, Nigeria; the collected bread wastes were sun-dried and milled using a hammer at the Nutrition Laboratory of the Department of
Animal Production and Health, The Federal University of Technology, Akure, Nigeria.

\section{Fortified bread waste production}

The milled fluted pumpkin leaves (FPLM) and milled bread wastes (BWM) were mixed together in ratio 1:9 $(1 \mathrm{~kg}$ FPLM $+9 \mathrm{~kg}$ BWM) to produce $10 \mathrm{~kg}$ fortified bread waste meal (FBWM). The reason for blending the bread waste with fluted pumpkin is to improve the nutritional quality of the bread waste, and the reason for using ratio 1:9 is not to make the diet too bulky. Other feed ingredients were sourced from feed-mills within Akure, Ondo State, Nigeria. The proximate compositions of bread waste and fortified bread waste were done using AOAC (2006) method, and the results are presented in Table 1.

\section{Experimental diets}

Four experimental diets were formulated for the starter phase to meet NRC (1994) minimum requirement. The four experimental broiler starter diets were formulated using fortified bread waste meal as one of the feed ingredients at the graded levels of $0,5,10$ and $15 \%$ and designated diets I, II, III and IV, respectively. The same procedure was followed for the finisher phase. Each diet was thoroughly mixed. The gross compositions of the experimental diets (starter and finisher phases) are shown in Tables 2 and 3.

\section{Experimental layout and feeding trials}

A total of two hundred day-old Abor-acre breed of broiler chicks were procured from a reputable hatchery in Ibadan, Nigeria, out of which two hundred chicks were randomly allotted to four dietary treatments replicated five times with ten chicks per replicate in a completely randomized design. The weight of each group (10 chicks) was balanced ( $\pm 1 \mathrm{~g})$. The birds were fed their respective starter diets from 1-28 days and their finisher diets from 29-56 days. The experimental diets and water were supplied ad libitum throughout the experimental period. Daily feed consumption and weekly weight changes were monitored. The feed conversion ratio (FCR) was calculated from the values obtained from daily feed consumption and weekly weight changes.

\section{Slaughtering, carcass and organ measurement}

At the end of the feeding trial (1-56 days), three birds per replicate were randomly selected and sacrificed. The birds were stunned and slaughtered for blood collection for the haematological and serum indices studies. For haematology, blood samples were collected into sterilized bottles containing speck of ethylene diamine tetra-acetic acid (EDTA) and blood samples for serum biochemical studies were collected into test tubes (without anticoagulant) and 
Table 1 nutritional composition of bread waste and fortified bread waste meal

\begin{tabular}{lll}
\hline Nutrient & $\begin{array}{l}\text { Bread } \\
\text { waste }\end{array}$ & $\begin{array}{l}\text { Fortified bread } \\
\text { waste meal }\end{array}$ \\
\hline Moisture content (\%) & 8.11 & 12.35 \\
Crude protein (\%) & 12.53 & 19.40 \\
Ether extract (\%) & 11.04 & 3.61 \\
Crude fibre (\%) & 2.25 & 1.10 \\
Ash (\%) & 4.80 & 1.90 \\
Calcium (\%) & 0.28 & 0.31 \\
Phosphorus (\%) & 0.52 & 0.57 \\
Nitrogen free extract (\%) & 61.27 & 61.64 \\
Metabolizable energy (kcal/kg) & 3452.38 & 3928.80 \\
\hline
\end{tabular}

placed in test tube racks, and after some hours, the serum was obtained by centrifugation and serum samples were stored in a deep freezer prior further study. Thereafter, the birds were defeathered, weighed and tagged dressed weight. The eviscerated weight was obtained by removal of the offal and internal organs. Carcass parts and organs

Table 2 Gross composition of the starter diets (\%)

\begin{tabular}{|c|c|c|c|c|}
\hline Ingredients & Diet I & Diet II & Diet III & Diet IV \\
\hline Maize & 53.05 & 49.55 & 46.05 & 42.05 \\
\hline Soybean & 17.00 & 15.50 & 14.00 & 13.00 \\
\hline Groundnut cake & 20.00 & 20.00 & 20.00 & 20.00 \\
\hline Fish meal & 3.00 & 3.00 & 3.00 & 3.00 \\
\hline Fortified bread waste & 0.00 & 5.00 & 10.00 & 15.00 \\
\hline Lysine & 0.10 & 0.10 & 0.10 & 0.10 \\
\hline Methionine & 0.10 & 0.10 & 0.10 & 0.10 \\
\hline Di-calcium phosphate & 1.00 & 1.00 & 1.00 & 1.00 \\
\hline Limestone & 2.00 & 2.00 & 2.00 & 2.00 \\
\hline Starter premix & 0.25 & 0.25 & 0.25 & 0.25 \\
\hline Vegetable oil & 3.00 & 3.00 & 3.00 & 3.00 \\
\hline Salt & 0.50 & 0.50 & 0.50 & 0.50 \\
\hline Total & 100 & 100 & 100 & 100 \\
\hline \multicolumn{5}{|l|}{ Calculated analysis: } \\
\hline Crude protein (\%) & 22.70 & 22.68 & 22.63 & 22.58 \\
\hline Metabolizable energy (Kcal/kg) & 3009.92 & 3006.31 & 3002.82 & 2999.27 \\
\hline Calcium (\%) & 1.12 & 1.13 & 1.14 & 1.14 \\
\hline Available phosphorus (\%) & 0.55 & 0.56 & 0.57 & 0.58 \\
\hline Lysine (\%) & 1.26 & 1.26 & 1.26 & 1.26 \\
\hline Methionine (\%) & 0.48 & 0.48 & 0.47 & 0.47 \\
\hline
\end{tabular}

Contained vitamins A (8,500,000 IU), D3 (1,500,000 IU), E (10,000 mg), K3 (1500 $\mathrm{mg}), \mathrm{B} 1(1600 \mathrm{mg}), \mathrm{B} 2(4000 \mathrm{mg}), \mathrm{B} 6(1500 \mathrm{mg}), \mathrm{B} 12(10 \mathrm{mg})$, niacin $(20,000$ $\mathrm{mg})$, pantothenic acid $(5000 \mathrm{mg})$, folic acid $(500 \mathrm{mg})$, biotin H2 $(750 \mathrm{mg})$, choline chloride $(175,000 \mathrm{mg})$, cobalt $(200 \mathrm{mg})$, copper (3000 mg), iodine (1000 mg), iron (20,000 mg), manganese $(40,000 \mathrm{mg})$, selenium $(200 \mathrm{mg})$, zinc $(30,000 \mathrm{mg})$, and antioxidant $(1250 \mathrm{mg})$ per $2.5 \mathrm{~kg}$
Table 3 Gross composition of the finisher diets (\%)

\begin{tabular}{|c|c|c|c|c|}
\hline Ingredients & Diet I & Diet II & Diet III & Diet IV \\
\hline Maize & 59.00 & 56.00 & 53.00 & 50.00 \\
\hline Soybean & 11.00 & 9.00 & 7.00 & 5.00 \\
\hline Groundnut cake & 20.00 & 20.00 & 20.00 & 20.00 \\
\hline Fish meal & 3.00 & 3.00 & 3.00 & 3.00 \\
\hline Fortified bread waste & 0.00 & 5.00 & 10.00 & 15.00 \\
\hline Lysine & 0.12 & 0.12 & 0.12 & 0.12 \\
\hline Methionine & 0.12 & 0.12 & 0.12 & 0.12 \\
\hline Di-calcium phosphate & 1.21 & 1.21 & 1.21 & 1.21 \\
\hline Limestone & 2.00 & 2.00 & 2.00 & 2.00 \\
\hline Premix & 0.25 & 0.25 & 0.25 & 0.25 \\
\hline Vegetable oil & 3.00 & 3.00 & 3.00 & 3.00 \\
\hline Salt & 0.30 & 0.30 & 0.30 & 0.30 \\
\hline Total & 100 & 100 & 100 & 100 \\
\hline \multicolumn{5}{|l|}{ Calculated analysis: } \\
\hline Crude protein (\%) & 19.70 & 19.65 & 19.60 & 19.55 \\
\hline Metabolizable energy (Kcal/kg) & 3030.24 & 3026.69 & 3023.14 & 3019.59 \\
\hline Calcium (\%) & 1.11 & 1.11 & 1.12 & 1.13 \\
\hline Available phosphorus (\%) & 0.50 & 0.51 & 0.52 & 0.53 \\
\hline Lysine (\%) & 1.10 & 1.10 & 1.10 & 1.10 \\
\hline Methionine (\%) & 0.40 & 0.40 & 0.40 & 0.40 \\
\hline
\end{tabular}

Contained vitamins A $(8,500,000 \mathrm{IU})$, D3 (1,500,000 IU), E (10,000 mg), K3 (1500 $\mathrm{mg}), \mathrm{B} 1(1600 \mathrm{mg}), \mathrm{B} 2(4,000 \mathrm{mg}), \mathrm{B} 6(1500 \mathrm{mg}), \mathrm{B} 12(10 \mathrm{mg})$, niacin $(20,000$ $\mathrm{mg})$, pantothenic acid $(5000 \mathrm{mg})$, folic acid $(500 \mathrm{mg})$, biotin H2 $(750 \mathrm{mg})$, choline chloride $(175,000 \mathrm{mg})$, cobalt $(200 \mathrm{mg})$, copper $(3000 \mathrm{mg})$, iodine $(1000 \mathrm{mg})$, iron $(20,000 \mathrm{mg})$, manganese $(40,000 \mathrm{mg})$, selenium $(200 \mathrm{mg})$, zinc $(30,000 \mathrm{mg})$, and antioxidant $(1,250 \mathrm{mg})$ per $2.5 \mathrm{~kg}$

were weighed and their weights expressed as percent of live body weight.

\section{Statistical analyses}

Collected data were subjected to one-way analysis of variance using SPSS version 13 package and where significant differences are found; the means were compared using Duncan multiple range test of the same package.

\section{Results \\ Performance characteristics}

The inclusion of bread waste fortified with Telfairia occidentalis leaf meal on the performance of broiler chickens is presented in Table 4. Among all the parameters measured, only the final weight and total weight gain were significantly $(P<0.05)$ influenced by the dietary treatments. The highest final weight $(2.12 \pm 13.16 \mathrm{~kg} /$ bird), the highest total weight gain $(2.08 \pm 13.14 \mathrm{~kg} / \mathrm{bird})$ and least feed conversion ratio $(2.32 \pm 0.02)$ were observed in birds fed diet I, while the lowest final weight $(1.73 \pm 11.67 \mathrm{~kg} / \mathrm{bird})$, the lowest total weight gain $(1.69$ $\pm 11.15 \mathrm{~kg} / \mathrm{bird})$ and highest feed conversion ratio $(2.57$ \pm 0.14 ) were observed in birds fed diet IV. The highest 
Table 4 Performance characteristics of broiler chickens fed with diets containing fortified bread waste meals

\begin{tabular}{lllll}
\hline Parameters & Diet I & Diet II & Diet III & Diet IV \\
\hline Initial weight(g/bird) & $40.92 \pm 0.34$ & $40.90 \pm 0.36$ & $40.92 \pm 0.34$ & $40.90 \pm 0.36$ \\
Final weight(kg/bird) & $2.12 \pm 13.16^{\mathrm{a}}$ & $2.01 \pm 12.01^{\mathrm{ab}}$ & $1.88 \pm 11.07^{\mathrm{b}}$ & $1.73 \pm 11.67^{\mathrm{b}}$ \\
Total weight gain $(\mathrm{kg} / \mathrm{bird})$ & $2.08 \pm 13.14^{\mathrm{a}}$ & $1.97 \pm 11.55^{\mathrm{ab}}$ & $1.84 \pm 10.59^{\mathrm{b}}$ & $1.69 \pm 11.15^{\mathrm{b}}$ \\
Total feed consumed $(\mathrm{kg} / \mathrm{bird})$ & $4.82 \pm 25.60$ & $4.73 \pm 25.40$ & $4.36 \pm 24.36$ & $4.35 \pm 24.32$ \\
Feed conversion ratio & $2.32 \pm 0.02$ & $2.40 \pm 0.09$ & $2.37 \pm 0.05$ & $2.57 \pm 0.14$ \\
\hline
\end{tabular}

${ }^{a, b}$ Mean within rows having different superscripts is significantly different $(P<0.05)$

total feed intake $(4.82 \pm 25.60 \mathrm{~kg} / \mathrm{bird})$ was observed in birds fed diet I and the lowest total feed intake $(4.35 \pm$ $24.32 \mathrm{~kg} /$ bird) were recorded in bird fed diet IV.

\section{Carcass characteristics}

Table 5 shows the carcass characteristics of birds fed graded levels of fortified bread waste meal. Among all the measured parameters, dressed weight, eviscerated weight, head, chest, drumstick, wing, thigh, back and shank were significantly $(P<0.05)$ influenced by the dietary treatments. Highest dressed weight (92.64 $\pm 8.30 \%)$, highest eviscerated weight (79.52 $\pm 6.50 \%)$, highest head ( $25.34 \pm 2.30 \mathrm{~g} / \mathrm{kg}$ body weight), highest chest $(206.53 \pm$ $14.50 \mathrm{~g} / \mathrm{kg}$ body weight) and highest wing (83.10 \pm 4.80 $\mathrm{g} / \mathrm{kg}$ body weight) were recorded in birds fed diet I, while lowest dressed weight $(84.13 \pm 5.15 \%)$, lowest eviscerated weight $(71.63 \pm 5.12 \%)$, lowest head (21.66 \pm $2.03 \mathrm{~g} / \mathrm{kg}$ body weight), lowest chest $(164.38 \pm 13.59 \mathrm{~g} / \mathrm{kg}$ body weight) and lowest wing $(75.50 \pm 4.10 \mathrm{~g} / \mathrm{kg}$ body weight) were recorded in birds fed diet IV. Also, highest drumstick (110.78 $\pm 12.50 \mathrm{~g} / \mathrm{kg}$ body weight), highest thigh $(115.78 \pm 10.87 \mathrm{~g} / \mathrm{kg}$ body weight), highest back (159.97 $\pm 13.60 \mathrm{~g} / \mathrm{kg}$ body weight) and highest shank $(42.20 \pm 4.20 \mathrm{~g} / \mathrm{kg}$ body weight) were recorded in birds fed diet II, while lowest drumstick $(93.64 \pm 11.33 \mathrm{~g} / \mathrm{kg}$ body weight), lowest thigh (99.45 $\pm 9.89 \mathrm{~g} / \mathrm{kg}$ body weight) and lowest shank (39.41 $\pm 3.34 \mathrm{~g} / \mathrm{kg}$ body weight) were recorded in birds fed diet IV and lowest back (143.03 $\pm 13.21 \mathrm{~g} / \mathrm{kg}$ body weight) was observed in bird fed diet III.

\section{Relative organ measurements:}

The relative organ weights of birds fed graded levels of fortified bread waste meal are shown in Table 6. For all the parameters measured, only the pancreas was significantly $(P<0.05)$ influenced by the dietary treatments. The highest pancreas $(2.75 \pm 0.22 \mathrm{~g} / \mathrm{kg}$ body weight $)$ and the lowest pancreas $(1.83 \pm 0.12 \mathrm{~g} / \mathrm{kg}$ body weight $)$ were recorded on birds fed diets IV and II, respectively. The relative weights are the following: gizzard (ranged 11.91 \pm 1.30 to $13.47 \pm 1.78 \mathrm{~g} / \mathrm{kg}$ body weight), liver (ranged $15.09 \pm 2.02$ to $17.27 \pm 2.22 \mathrm{~g} / \mathrm{kg}$ body weight), heart (ranged $3.55 \pm 0.04$ to $4.12 \pm 0.18 \mathrm{~g} / \mathrm{kg}$ body weight) and lung (ranged $4.10 \pm 0.21$ to $4.46 \pm 0.42 \mathrm{~g} / \mathrm{kg}$ body weight). The highest values for gizzard and heart were observed in birds fed diet III $(13.47 \pm 1.78 \mathrm{~g} / \mathrm{kg}$ body weight and $4.12 \pm 0.18 \mathrm{~g} / \mathrm{kg}$ body weight, respectively), while the lowest values for gizzard and heart were recorded in birds fed diet II and diet I $(11.91 \pm 1.30 \mathrm{~g} / \mathrm{kg}$ and $3.55 \pm 0.04 \mathrm{~g} / \mathrm{kg}$, respectively). The highest value for liver $(17.27 \pm 2.22 \mathrm{~g} / \mathrm{kg}$ body weight) was recorded in bird fed diet IV, while the lowest value $(15.09 \pm 2.02 \mathrm{~g} /$ $\mathrm{kg}$ body weight) was recorded in bird fed diet II. Highest belly fat (15.47 $\pm 1.62 \mathrm{~g} / \mathrm{kg}$ body weight) was recorded in bird fed diet II, while lowest belly fat $(10.12 \pm 1.20 \mathrm{~g} / \mathrm{kg}$ body weight) was recorded in bird fed diet I.

Table 5 Carcass traits (g) of broiler chickens fed with diets containing fortified bread waste meals

\begin{tabular}{lllll}
\hline Parameters & Diet I & Diet II & Diet III & Diet IV \\
\hline Dressed weight (\%) & $92.64 \pm 8.30^{\mathrm{a}}$ & $91.97 \pm 7.67^{\mathrm{ab}}$ & $88.00 \pm 6.57^{\mathrm{bc}}$ & $84.13 \pm 5.15^{\mathrm{c}}$ \\
Eviscerated weight (\%) & $79.52 \pm 6.50^{\mathrm{a}}$ & $79.46 \pm 6.51^{\mathrm{ab}}$ & $73.33 \pm 6.66^{\mathrm{bc}}$ & $71.63 \pm 5.12^{\mathrm{c}}$ \\
Head (g/kg body weight) & $25.34 \pm 2.30^{\mathrm{a}}$ & $24.72 \pm 2.15^{\mathrm{ab}}$ & $22.68 \pm 2.11^{\mathrm{bc}}$ & $21.66 \pm 2.03^{\mathrm{c}}$ \\
Chest (g/kg body weight) & $206.53 \pm 14.50^{\mathrm{a}}$ & $195.67 \pm 14.40^{\mathrm{ab}}$ & $167.14 \pm 14.15^{\mathrm{bc}}$ & $164.38 \pm 13.59^{\mathrm{c}}$ \\
Drumstick (g/kg body weight) & $106.42 \pm 12.30^{\mathrm{ab}}$ & $110.78 \pm 12.50^{\mathrm{a}}$ & $100.25 \pm 11.80^{\mathrm{bc}}$ & $93.64 \pm 11.33^{\mathrm{c}}$ \\
Wing (g/kg body weight) & $83.10 \pm 4.80^{\mathrm{a}}$ & $82.91 \pm 4.68^{\mathrm{a}}$ & $80.52 \pm 4.38^{\mathrm{ab}}$ & $75.50 \pm 4.10^{\mathrm{c}}$ \\
Thigh (g/kg body weight) & $112.95 \pm 10.60^{\mathrm{a}}$ & $115.78 \pm 10.87^{\mathrm{a}}$ & $101.13 \pm 10.06^{\mathrm{bc}}$ & $99.45 \pm 9.89^{\mathrm{c}}$ \\
Neck (g/kg body weight) & $38.48 \pm 3.60$ & $32.80 \pm 3.32$ & $41.59 \pm 3.89$ & $38.82 \pm 3.69$ \\
Back (g/kg body weight) & $158.83 \pm 13.40^{\mathrm{ab}}$ & $159.97 \pm 13.60^{\mathrm{a}}$ & $143.03 \pm 13.21^{\mathrm{b}}$ & $144.57 \pm 13.27^{\mathrm{b}}$ \\
Shank (g/kg body weight) & $42.03 \pm 4.15^{\mathrm{ab}}$ & $42.20 \pm 4.20^{\mathrm{ab}}$ & $41.27 \pm 3.77^{\mathrm{b}}$ & $39.41 \pm 3.34^{\mathrm{c}}$ \\
\hline
\end{tabular}

$\overline{\mathrm{a}, \mathrm{b}, \mathrm{c}}$ Mean within rows having different superscripts is significantly different $(P<0.05)$ 
Table 6 Organ weight ( $\mathrm{g} / \mathrm{kg}$ body weight) of broiler chickens fed with diets containing fortified bread waste meals

\begin{tabular}{lllll}
\hline Parameters & Diet I & Diet II & Diet II & Diet IV \\
\hline Liver & $16.08 \pm 2.11$ & $15.09 \pm 2.02$ & $16.48 \pm 2.13$ & $17.27 \pm 2.22$ \\
Heart & $3.55 \pm 0.04$ & $3.78 \pm 0.09$ & $4.12 \pm 0.18$ & $3.58 \pm 0.06$ \\
Lung & $4.10 \pm 0.21$ & $4.29 \pm 0.26$ & $4.33 \pm 0.28$ & $4.46 \pm 0.42$ \\
Gizzard & $12.54 \pm 1.44$ & $11.91 \pm 1.30$ & $13.47 \pm 1.78$ & $12.75 \pm 1.58$ \\
Spleen & $1.82 \pm 0.13$ & $1.75 \pm 0.09$ & $1.80 \pm 0.11$ & $1.57 \pm 0.06$ \\
Pancreas & $2.41 \pm 0.18^{\mathrm{a}}$ & $1.83 \pm 0.12^{\mathrm{bc}}$ & $2.10 \pm 0.13^{\mathrm{b}}$ & $2.75 \pm 0.22^{\mathrm{a}}$ \\
Proventriculus & $3.41 \pm 0.19$ & $3.94 \pm 0.26$ & $3.27 \pm 0.15$ & $3.09 \pm 0.11$ \\
Belly fat & $10.12 \pm 1.20$ & $15.47 \pm 1.62$ & $11.20 \pm 1.30$ & $14.17 \pm 1.50$ \\
\hline $\begin{array}{l}\text { a,b,c Mean within rows having different superscripts is significantly different }(P \\
<0.05)\end{array}$ & & &
\end{tabular}

\section{Haematological indices}

The results of haematological indices of birds fed graded levels of fortified bread waste meal are shown in Table 7. For all the measured parameters, only lymphocyte was significantly $(P<0.05)$ influenced by the dietary treatments. Highest lymphocyte $(60.17 \pm 0.28 \%)$ was recorded in birds fed diet II, while lowest lymphocyte $(58.83 \pm 0.15 \%)$ was recorded in bird fed diet IV. Numerically, highest erythrocyte sedimentation rates $(3.33 \pm 0.19 \mathrm{~mm} / \mathrm{h})$, mean cell volume $\left(150.68 \pm 8.40 \mu^{3}\right)$, mean cell haemoglobin (52.09 $\pm 0.69 \mathrm{pg}$ of $\mathrm{Hb}$ ) and mean cell haemoglobin concentration $(34.57 \pm 0.10 \%)$ were observed in birds fed diet II, while the lowest erythrocyte sedimentation rates $(2.00 \pm$ $0.10 \mathrm{~mm} / \mathrm{h})$, mean cell volume $\left(121.65 \pm 8.08 \mu^{3}\right)$, mean cell haemoglobin $(40.93 \pm 0.48 \mathrm{pg}$ of $\mathrm{Hb})$ and mean cell haemoglobin concentration $(33.65 \pm 0.15 \%)$ were observed in birds fed diet III. Highest packed cell volume (28.83 \pm $0.21 \%)$ and highest red blood cell $\left(2.37 \pm 0.13 \times 10^{6} / \mathrm{mm}^{3}\right)$ were recorded in birds fed diet III while lowest packed cell volume $(26.67 \pm 0.27 \%)$ and lowest red blood cell $(1.77 \pm$ $0.04 \times 10^{6} / \mathrm{mm}^{3}$ ) were recorded in birds fed diet II.
Neutrophil (varied $24.17 \pm 0.27$ to $25.00 \pm 0.43 \%$ ), monocytes (varied $11.33 \pm 0.12$ to $12.50 \pm 0.22 \%$ ), basophil (varied $2.00 \pm 0.03$ to $2.33 \pm 0.08 \%$ ) and eosinophil (varied $0.83 \pm 0.03$ to $1.00 \pm 0.05 \%)$.

\section{Serum indices}

Table 8 shows the biochemical indices of birds fed graded levels of fortified bread waste meal. Among all parameters measured, only alkaline phosphatase and cholesterol were significantly $(P<0.05)$ influenced by the dietary treatments. The birds fed diet I had the highest alkaline phosphatase $(150.98 \pm 9.80 \mathrm{IU} / \mathrm{I})$ while the lowest alkaline phosphate $(140.99 \pm 9.12)$ were observed in bird fed diet II. Lowest cholesterol $(21.23 \pm 3.15 \mathrm{mg} /$ dl) was recorded in bird fed diet IV while highest cholesterol $(32.78 \pm 3.78 \mathrm{mg} / \mathrm{dl})$ was observed in bird fed diet I. The highest total protein $(4.47 \pm 0.22 \mathrm{~g} / \mathrm{dl})$ and the lowest total protein $(3.97 \pm 0.15 \mathrm{~g} / \mathrm{dl})$ were observed in birds fed diets IV and III, respectively. The highest globulin $(2.81 \pm 0.16 \mathrm{~g} / \mathrm{dl})$ was observed in bird fed diet I, while the lowest globulin $(2.45 \pm 0.09 \mathrm{~g} / \mathrm{dl})$ was observed in bird fed diet II. The highest aspartate transamine and alanine aminotransferase $(29.75 \pm 2.78 \mathrm{IU} / \mathrm{I}$ and $13.53 \pm 1.58 \mathrm{IU} / \mathrm{I}$,) were observed in birds fed diet II, while the lowest aspartate transamine and alanine aminotransferase $(18.75 \pm 2.03 \mathrm{IU} / \mathrm{I}$ and $8.70 \pm 1.18 \mathrm{IU} / \mathrm{I}$, $)$ were observed in birds fed diet I.

\section{Economy of production}

Highest cost of experimental diet (N 101.5/ kg), cost of feed consumed ( $\mathrm{N} 489.23$ /bird) and total cost of production ( $\mathrm{N}$ 899.23) were recorded in birds fed diet I, while lowest cost of experimental diet $(\mathrm{N} 93.5 / \mathrm{kg})$, cost of feed consumed (N 406.73/bird) and total cost of production ( $\mathrm{N}$ 816.73) were recorded in birds fed diet IV. Highest net profit ( $\mathrm{N}$ 683.27) was recorded in bird fed diet IV.

Table 7 Haematological parameters of broiler chickens fed with diets containing fortified bread waste meals

\begin{tabular}{|c|c|c|c|c|}
\hline Parameters & Diet I & Diet II & Diet III & Diet IV \\
\hline Erythrocyte sedimentation rate $(\mathrm{mm} / \mathrm{h})$ & $2.83 \pm 0.14$ & $3.33 \pm 0.19$ & $2.00 \pm 0.10$ & $2.67 \pm 0.13$ \\
\hline Packed cell volume (\%) & $27.55 \pm 0.23$ & $26.67 \pm 0.27$ & $28.83 \pm 0.21$ & $28.50 \pm 0.24$ \\
\hline Red blood cell $\left(\times 10^{6} / \mathrm{mm}^{3}\right)$ & $2.10 \pm 0.07$ & $1.77 \pm 0.04$ & $2.37 \pm 0.13$ & $2.25 \pm 0.09$ \\
\hline Haemoglobin concentration (g/100 ml) & $9.48 \pm 1.40$ & $9.22 \pm 1.18$ & $9.70 \pm 1.72$ & $9.83 \pm 1.83$ \\
\hline Mean cell volume $\left(\mu^{3}\right)$ & $131.19 \pm 8.27$ & $150.68 \pm 8.40$ & $121.65 \pm 8.08$ & $126.67 \pm 8.20$ \\
\hline Mean cell haemoglobin (pg of $\mathrm{Hb}$ ) & $45.14 \pm 0.57$ & $52.09 \pm 0.69$ & $40.93 \pm 0.48$ & $43.69 \pm 0.54$ \\
\hline Mean cell haemoglobin concentration (\%) & $34.41 \pm 0.02$ & $34.57 \pm 0.10$ & $33.65 \pm 0.15$ & $34.49 \pm 0.05$ \\
\hline Lymphocytes (\%) & $59.00 \pm 0.23^{b c}$ & $60.17 \pm 0.28^{a}$ & $59.00 \pm 0.23^{b c}$ & $58.83 \pm 0.15^{c}$ \\
\hline Neutrophils (\%) & $25.00 \pm 0.43$ & $24.33 \pm 0.31$ & $24.50 \pm 0.37$ & $24.17 \pm 0.27$ \\
\hline Monocytes (\%) & $12.33 \pm 0.18$ & $11.50 \pm 0.15$ & $12.50 \pm 0.22$ & $11.33 \pm 0.12$ \\
\hline Basophils (\%) & $2.17 \pm 0.05$ & $2.00 \pm 0.03$ & $2.17 \pm 0.05$ & $2.33 \pm 0.08$ \\
\hline Eosinophil (\%) & $1.00 \pm 0.05$ & $1.00 \pm 0.05$ & $0.83 \pm 0.03$ & $0.83 \pm 0.03$ \\
\hline
\end{tabular}

$\overline{\mathrm{a}, \mathrm{b}, \mathrm{c}}$ Mean within rows having different superscripts are significantly different $(P<0.05)$ 
Table 8 Serum indices of broiler chicken fed with diets containing graded level of fortified bread waste meals

\begin{tabular}{|c|c|c|c|c|}
\hline Parameters & Diet I & Diet II & Diet III & Diet IV \\
\hline Total protein (g/dl) & $4.03 \pm 0.17$ & $4.42 \pm 0.20$ & $3.97 \pm 0.15$ & $4.47 \pm 0.22$ \\
\hline Albumin (g/dl) & $1.22 \pm 0.02$ & $1.97 \pm 0.10$ & $1.37 \pm 0.05$ & $2.01 \pm 0.12$ \\
\hline Globulin (g/dl) & $2.81 \pm 0.16$ & $2.45 \pm 0.09$ & $2.60 \pm 0.12$ & $2.46 \pm 0.11$ \\
\hline Creatinine $(\mathrm{mg} / \mathrm{dl})$ & $0.14 \pm 0.03$ & $0.38 \pm 0.05$ & $0.33 \pm 0.04$ & $0.68 \pm 0.09$ \\
\hline Alkaline phosphatase (IU/I) & $150.98 \pm 9.80^{a}$ & $140.99 \pm 9.12^{c}$ & $142.62 \pm 9.18^{b c}$ & $145.05 \pm 9.42^{b}$ \\
\hline Cholesterol (mg/dl) & $32.78 \pm 3.78^{a}$ & $26.82 \pm 3.52^{b}$ & $23.03 \pm 3.28^{b c}$ & $21.23 \pm 3.15^{c}$ \\
\hline Alanine aminotransferase (IU/I) & $8.70 \pm 1.18$ & $13.53 \pm 1.58$ & $11.00 \pm 1.25$ & $11.20 \pm 1.37$ \\
\hline Aspartate transamine (IU/I) & $18.75 \pm 2.03$ & $29.75 \pm 2.78$ & $25.00 \pm 2.47$ & $24.50 \pm 2.31$ \\
\hline
\end{tabular}

$\overline{a, b, c}$ Mean within rows having different superscripts are significantly different $(P<0.05)$

As the levels of fortified bread waste meal increases in the diet, profit obtained increases (Table 9). Cost of dayold chicks, cost of drug and vaccinations per bird and sale price per bird were the same for all the treatments.

\section{Discussion}

The obtained results from this study showed that the growth in terms of body weight of the birds fed at varying level of bread waste fortified with fluted pumpkin leaf meals was significantly different $(P<0.05)$ for final weight and total weight gain of the birds. The results obtained from the total weight gain of this study was in agreement with the report of Leeson et al. (1996) that the increased growth rate of broiler chicken is achieved by an increase in feed intake. Total feed consumed by all the experimental birds were not significantly $(P>0.05)$. The depression in growth rate, which is as a result of high feed conversion ratio in birds fed diet IV and inconsistency in feed intake for the treatment suggested poor utilization of this diet. Olabode (2008) and Onyimonyi et al. (2009) both worked with neem leaf meal, and they also observed the low level of feed intake in broiler birds as the level of NLM increased in the diet of the birds. These authors suggested that the low palatability, nutrient imbalance and bitterness of the diets as imparted by the neem leaf meal could be responsible for the low feed intake. According to Brown et al. (2001)

Table 9 Economics of broiler chicken fed with diets containing graded level of fortified bread waste meals

\begin{tabular}{lllll}
\hline Parameters & Diet I & Diet II & Diet III & Diet IV \\
\hline Cost of day-old chick (N) & 160 & 160 & 160 & 160 \\
Cost of experimental diets (N/kg) & 101.5 & 97.0 & 75.0 & 93.5 \\
Total feed consumed (kg/bird) & 4.82 & 4.73 & 4.36 & 4.35 \\
Cost of feed consumed (N/bird) & 489.23 & 458.81 & 414.20 & 406.73 \\
Cost of drug + vaccine (N/bird) & 250 & 250 & 250 & 250 \\
Total cost of production (N/bird) & 899.23 & 868.81 & 824.20 & 816.73 \\
Sale price of bird (N/Bird) & 1500 & 1500 & 1500 & 1500 \\
Net profit/bird produced (N) & 600.70 & 631.19 & 675.80 & 683.27 \\
\hline
\end{tabular}

who reported that comparison of feed conversion ratio among different species may be of little significance unless the feed involves are of similar quality and suitability. The result obtained in this study shows that the birds on the test diets can turn feed to body mass. Diet I had more ability to turn feed to body mass due to their low feed conversion ratio value and followed by diet III and diet II. This result agrees with the findings of $\mathrm{Al}$ Ruqaie et al. (2011) who reported that bread waste product (BWP) could replace $100 \%$ of the corn in broiler diets without any adverse effect on the performance.

The carcass has been known to be an important parameter for determining the relationship for the "wholesale" or "further process" base of birds. The output quality for the system is fixed by a predetermined amount of kilogramme carcass of the final product of broilers (Warren and Emmert, 2000). In this study, the dressed weight, eviscerated weight, head, breast, and wing of the birds decreased progressively as the levels of inclusion of the fortified bread wastes increased in the diets. This implies that the decreased in these carcass weights at increased inclusion levels of the fortified bread wastes could be as a result of the effect of fibre which increased in the diets. Preston and William (1973) who reported that heavier birds at slaughter would have greater dressing percentage and higher eviscerated yield than lighter birds

The weight of organs in broilers according to Atteh (2004) reflects the anatomical response of birds to the type of diet consumed. Liver, heart, gizzard, spleen, proventriculus and belly fat weights were generally similar $(P>0.05)$ for all the experimental birds showing that the fortified bread wastes were not detrimental to the birds. This was in agreement with Ani et al. (2013) who reported that dressing percentage, liver, heart, spleen, gizzard, small and large intestine weights were generally similar for treated and control groups showing that Gongronema latifolium inclusion in the diets was not detrimental to the birds.

Blood is a means of assessing both clinical and nutritional health status of animals in feeding trials (Aderemi, 
2004). Haematological profiles such as red blood cell, packed cell volume, white blood cell and haemoglobin concentration have all been found useful for disease prognosis, for therapeutic and feed stress monitoring (Olafedehan et al. 2010). The results of the haematological profiles showed that the mean cell haemoglobin, neutrophils, eosinophils, monocyte, erythrocyte sedimentation rate, basophils, packed cell volume, red blood cell, mean cell volume, mean cell haemoglobin concentration and haemoglobin of all the birds in the treatments were not influenced by the varied inclusion level of the fortified bread wastes. The values for all the haematological profiles determined in this experiment fell within the range presented by Maton et al. (2004). The obtained results in this study also buttresses the point that the fortified bread waste could be used as an alternative feed ingredient without any adverse effect on the health status of the birds.

It has been established that a high value of serum total protein is a good indicator of quality protein in experimental diets (Tewe, 1985; Aletor et al., 1998). The obtained results of biochemical indices from this present study show that the total protein, albumin, globulin, creatinine, aspartate transamine and alanine aminotransferase were not influenced at varying inclusion levels of the fortified bread wastes in the diets. In this study, the serum total protein values were not significantly affected by the dietary treatments which suggest the adequacy and utilization of the dietary protein by the birds irrespective of the varying inclusion in the fortified bread wastes. The function of albumin in the blood have been reported to include the facilitation of blood clotting ability in farm animals, the higher the albumin the higher the clotting ability and hence its ability to prevent haemorrhage (Azeez et al., 2002). However, the value of albumin obtained in this study was in line with the range of reported by Adegoke et al. (2018). Globulin prevents infection in an animal by providing antibodies which fights infection (Awojobi and Opiah, 2000). Adegbenro et al. (2016) reported that low globulin levels could lead to high mortality. A normal range of 3-3.5 g/dl was reported by Mitruka and Rawnsley (1977). Alkaline phosphatase (ALP), alanine aminotransferase (ALT) and aspartate transamine (AST) are major indicators used for assessing the liver condition of animals (Agbede et al., 2011). Alanine aminotransferase (ALT) and aspartate transamine (AST) were not affected at varying level of the fortified bread wastes in the diets, and this is a good indicator that the fortified bread wastes might not pose any serious health challenges to the birds, especially the liver, as increased activities of these enzymes are a well-known diagnostic indicator of liver injury (Agbede et al., 2011).

Cost of production and cost of feed decrease progressively as the inclusion of fortified bread waste meal increases. The economy of production revealed that the cost of feed per kilogramme of feed and cost of feed per gain were affected by the dietary treatments. The variation in the cost of feed and production indicated that diet IV had the least cost of experimental diet, feed consumed and cost of production. This result agrees with the findings of Oke (2013) who reported that the inclusion of $30 \%$ level bread waste meal in the diets of broiler chickens led to a reduction in the cost of feed, cost of feed $/ \mathrm{kg}$ weight gain, cost of production and improvement in the profit margin. However, the highest profit was generated from bird fed diet IV compared to other birds fed diets I-III. Zahari and Alimon (2006) had earlier reported improvement in the feed efficiency through the accelerated use of local feedstuff in other to reduce high production cost thereby increasing profit

\section{Conclusion}

From the obtained results in this study, it can be concluded that increasing levels of fortified bread wastes in replacing maize in broiler chicken diets can be practised. It can be therefore recommended that $5 \%$ fortified bread waste inclusion level will perform well considering the performance, carcass, organ results and blood indices. Also, the obtained results from the net profit was an indication that fortified bread waste could serve as alternative feed resources in broiler chicken diets.

\section{Abbreviations}

FPLM: Fluted pumpkin leaf meal; BWM: Bread waste meal; FBWM: Fortified bread waste meal

\section{Authors' contributions}

MA, JOA and VAA suggested the study and participated in the design and coordination. All authors (MA, OAA, JOA and VAA) carried out the feeding trial, sample collection and analysis. MA and OAA carried out statistical data analysis and interpret the results. MA, OAA, JOA and VAA search for literature and prepared the first draft of the manuscript. All authors read and approved the final manuscript

Funding

This study was not funded by any institution or any other entity.

\section{Availability of data and materials}

The datasets generated and analysed during this study are available from the corresponding author on reasonable request.

Ethics approval and consent to participate

The right to conduct the research granted by the Research Committee of the Department of Animal Production and Health, Federal University of Technology, Akure, Nigeria. The birds were managed following the recommendation and guidelines of the committee.

Consent for publication

Not applicable.

Competing interests

The authors declare that they have no competing interests. 
Received: 25 March 2020 Accepted: 28 May 2020

Published online: 16 June 2020

\section{References}

Adegbenro, M. (2015). Characterization of some tropical leaves and their replacement values for commercial vitamin/mineral premix in poultry and swine diets. PhD Thesis Submitted in the Department of Animal Production and Health, School of Agriculture and Agricultural Technology, Federal University of Technology, Akure, Nigeria.

Adegbenro M, Agbede JO, Onibi GE, Aletor VA (2016) Composite leaf meal: effects on haematology and biochemical indices of growing pigs. Archiva Zootechnica 19(2):65

Adegoke AV, Abimbola MA, Sanwo KA, Egbeyale LT, Abiona JA, Oso AO, Iposu SO (2018) Performance and blood biochemistry profile of broiler chickens fed dietary turmeric (Curcuma longa) powder and Cayenne pepper (Capsicum frutescens) powder as antioxidants. Vet Animal Sci 6:95-102.s

Aderemi, V. A. (2004). Feeding differently processed soybean: an assessment of haematological responses in chickens. pp: 364-369.

Agbede JO, Arimah AA, Adu OA, Olaleye MT, Aletor VA (2011) Growth enhancing health impact and bacteria suppressive property of lanthanum supplementation in broiler chicken. Archivazootechnical 14(2):44-56

Ajibade JP, Akinfala EO, Aderibigbe AO, Matanmi O (2001) Evaluation of the nutritive value of whole cassava plant as a replacement for maize in the starter diets for broiler chicken. Livest Res Rural Dev 14:1-6 http://www.Irrd. org//rrd14/6akin146.htm

Alada A (2000) The haematological effect of Telfairia occidentalis diet preparation.African journal of biomedical Research.3:185-186.

Aletor, V. A., Agbede, J. O. and Sobayo, R. A. (1998).Haematological and Biochemical aspects of feeding broiler chicken conventional or under-utilized protein sources NSAP proceeding shield at Gateway hotel, Abeokuta. Pp: 157-160

Al-Ruqaie IM, Swillian SA, Al-Batshan A, Shafey TM (2011) Performance, nutrient utilization and economic impact of broiler chickens fed extruded bakery waste. J Animal Vet Adv 10:2061-2066

Ani AO, Ogbu CC, Abakasanga IU, Ugwuowo LC (2013) The response of broiler birds to varying dietary levels of Gongronema latifolium leaf meal. J Biol Agric Healthcare 3(14):67-74

AOAC (Association of Official Analytical Chemicals), (2006).Official Method of analysis of the AOAC. (Editor $18^{\text {th }}$ Edition), Washington, D. C.

Atteh, J. O. (2004). Theory and practice of poultry production: Adlek Printer Ilorin, Nigeria. pp 65-66.

Awojobi, H. A. and Opiah, G. O. (2000).The effect of physiological status on some blood parameter of the New Zealand white doe rabbits.Proceedings of Animal Science Association of Nigeria, 14-16.

Azeez KM, Bobade PA, Oduye OO, Helen OA (2002) Haemogram of clinically normal chickens with particular reference to local breeds and exotic breeds. Nigeria Vet J 14:7-11

Brown, I., Hindmarsh, R. and McGregor, R. (2001). Dynamic Agricultural Book Three, 2nd edition McGraw-Hill Book Company, Sydney by Oxford and IBH Co. PVT LTD, New Delhi, pp:134-135.

Fasuyi AO (2000) Biochemical, nutritional and socioeconomic aspect of cassava (Manhiotesculenta, coranzt) anti nutrition. Pakistian J Nutr 4:37-42

Ladeji O, Okoye Z, Ojobe T (1995) Chemical evaluation of the nutritive value of leave of fluted pumpkin (Telfairia occidentalis). Food Chem 53(4):353-355

Leeson S, Caston L, Summers JD (1996) Broiler response to diet energy. Poult Sci 75:529-535

Maton, J. A., Hopkins, J. C., Susan J. M., Maryanna, Q. W., David, L., and Jill, D. W. (2004). Human Biology and Health.ISBN 0-14-862145-2.

Mitruka BM, Rawnsley HM (1977) Clinical biochemical and hematological reference values in normal experimental animals. Masson Publishing Incorporation, USA, pp 134-135

National Research Council (1994). Nutrient requirement of poultry. Ninth revised edition.

Nworgu FC, Adebowale EA, Oredein OA, Oni A (1999) Prospects and economics of broiler chicken production using two plant protein sources. Trop J Animal Sci 2(1):159-166

Oke, O. S. (2013). Utilization of bread waste meal as replacement for maize in diets for broiler chickens. Journal of Poverty, Investment and Development Vol. 1

Olabode, A. D. (2008).The effect of supplemental neem (Azadirachta indica) leaf meal on the performance of broiler birds. MSc. Research work submitted to the Department of Animal Science. University of Nigeria, Nsukka. pp.3 -17.
Olafedehan, O. O., Obun, A. M., Yusuf, M. K., Adewumi, O. O., Olafedehan, A. O., Awofolaji, A. O., and Adeniji, A. A. (2010). Effects of residual cyanide in processed cassava peal meals on haematological and biochemical indices of growing rabbitsProceedings of 35th Annual Conference of Nigerian Society for Animal Production. pp: 212.

Onyimonyi AE, Adeyemi O, Okeke GC (2009) Performance and economic characteristic of broiler fed varying levels of neem leaf meal (Azardiratchtaindica). Int J Poult Sci 8:256-259

Preston LH, William WM (1973) Eviscerated yield, component parts and meat, skin bone ratios in chicken broiler. Poult Sci 52:718-722

Tewe 00 (1985) Protein metabolism in growing pigs fed corn or cassava peel based diets containing graded protein levels. Res Vet Sci 38:259-263

Warren WA, Emmert JL (2000) Efficacy of phase-feeding in supporting growth performance of broiler chicks during the starter and the finisher phases. Poultry science, 79:764-770

Zahari MW, Alimon AR (2006) Use of palm kernel cake and oil palm by-products in compound feed. Palm Oil Dev 40(1):5-9

\section{Publisher's Note}

Springer Nature remains neutral with regard to jurisdictional claims in published maps and institutional affiliations.

\section{Submit your manuscript to a SpringerOpen ${ }^{\bullet}$ journal and benefit from:}

- Convenient online submission

- Rigorous peer review

- Open access: articles freely available online

- High visibility within the field

- Retaining the copyright to your article

Submit your next manuscript at $>$ springeropen.com 